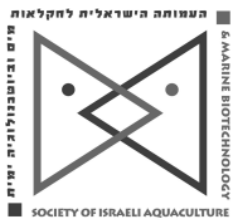

The IJA appears exclusively as a peerreviewed on-line Open Access journal at http://www.siamb.org.il Sale of IJA papers is strictly forbidden.

\title{
Population Growth of Bosmina longirostris Fed Chlorella vulgaris and Scenedesmus subspicatus in Different Densities
}

\section{Ömer Osman Ertan $*^{1}$, Zekiye Güçlü ${ }^{1}$, Ömer Erdoğan ${ }^{1}$, Sevgi Savaş ${ }^{1}$, İskender Gülle ${ }^{2}$}

${ }^{1}$ Faculty of Fisheries, Süleyman Demirel University, Eğirdir, Isparta, Türkiye

${ }^{2}$ Department of Biology, Faculty of Arts and Science, Mehmet Akif Ersoy University, Burdur, Türkiye

(Received 19.2.10, Accepted 29.3.10)

Key words: Chlorella, Scenedesmus, population growth, cladocera, Bosmina longirostris

\begin{abstract}
In this study, the effects of the different densities of Chlorella vulgaris $\left(0.05 \times 10^{6}, 0.1 \times 10^{6}, 0.2 \times 10^{6}, 0.4 \times 10^{6}\right.$, or $0.8 \times 10^{6}$ cells $/ \mathrm{ml})$ and Scenedesmus subspicatus $\left(0.05 \times 10^{6}, 0.1 \times 10^{6}, 0.2\right.$ $\times 10^{6}$, or $0.4 \times 10^{6}$ cells $/ \mathrm{ml}$ ) on culture of the water flea, Bosmina longirostris, were investigated. The experiment was carried out in a photoperiod of $16 \mathrm{~h}$ light: $8 \mathrm{~h}$ dark at $25 \pm 1^{\circ} \mathrm{C}$. At the beginning of the experiment, one $B$. longirostris individual ( $<24 \mathrm{~h}$ old) was put into each vessel, and the number of individuals and rate of population increase were determined for 30 days. Increasing the food density increased the number of individuals and the rate of population. The maximum number of $B$. longirostris individuals $(7.1 \pm 2.08 \mathrm{ind} / \mathrm{ml})$ and maximum rate of population increase $\left(0.2 \pm 0.004 /\right.$ day) was in the group fed $0.2 \times 10^{6}$ cells $/ \mathrm{ml} \mathrm{S}$. subspicatus. The effect on the number of the individuals was statistically significant $(p<0.05)$.
\end{abstract}

* Corresponding author. E-mail: ooertan@sdu.edu.tr 


\section{Introduction}

Among freshwater zooplanktons, protozoans, rotifers, cladocerans, and copepods are numerically more abundant than other groups. In terms of biomass, rotifers and crustaceans (cladocerans and copepods) are often the dominant group (Mangas-Ramirez et al., 2002; Nandini and Sarma, 2002). Because of their high sensitivity to changes in the physico-chemical characteristics of natural water systems, there are sometimes only a few cladoceran species present as dominant groups. For example, Bosmina, Cercopagis, and Daphnia are usually wide-spread in temperate water, while Ceriodaphnia, Moina, and Simocephalus attain higher densities in tropical waters (Mangas-Ramirez et al., 2002).

The most important environmental factors controlling the growth and reproduction of cladocerans are temperature (Benider et al., 2002; Vijverberg and Koelewijn, 2004) and food quantity and quality (Bocanegra et al., 2002; Abrantes and Gonçalves, 2003). Food density is one of the most important and commonly affecting factors for cladocerans both in the field and under laboratory conditions (Nandini and Sarma, 2000).

The effects of food on the dynamics of cladoceran species is a wellresearched subject. Most studies focus on Daphnia species but some focus on the dynamics of smaller cladocerans such as Ceriodaphnia, Moina, and Simocephalus (Nandini and Sarma, 2000; Mangas-Ramirez et al., 2002; Ovie and Egborge, 2002; Abrantes and Gonçalves, 2003). The aim of the present work was to determine the effect of different densities of two species of algae (Chlorella vulgaris and Scenedesmus subspicatus) on the population growth of the water flea, Bosmina longirostris.

\section{Materials and Methods}

Bosmina longirostris were originally isolated from Lake Eğirdir (Turkey). Experimental animals brought from the field were maintained in controlled laboratory conditions for more than six months. Certified strains of Chlorella vulgaris (SAG 211-11n) and Scenedesmus subspicatus (SAG 54.80) were obtained from Sammlung von Algenkulturen der Universitat Göttingen (SAG, Germany). The algae were mass cultured in transparent 6-I bottles and subcultured in 250-ml Erlenmeyer flasks, using autoclaved Bold-Basal medium (Borowitzka and Borowitzka, 1988). Algae harvested during the log-phase were centrifuged and resuspended in autoclaved well water. The density of the stock algal concentrates of each species was estimated using a Neubauer counting chamber.

To assess the effects of food type and densities on $B$. longirostris reproduction, we established 27 treatments based on densities of $0.05 \times 10^{6}$, $0.1 \times 10^{6}, 0.2 \times 10^{6}, 0.4 \times 10^{6}$, and $0.8 \times 10^{6} \mathrm{cells} / \mathrm{ml}$ for $C$. vulgaris and 0.05 $\times 10^{6}, 0.1 \times 10^{6}, 0.2 \times 10^{6}$, and $0.4 \times 10^{6}$ cells $/ \mathrm{ml}$ for S. subspicatus. Each treatment had three replicates. The experiments were conducted in $30-\mathrm{ml}$ transparent tubes, each with $10 \mathrm{ml}$ of medium containing the specified type and density of algae. Experiments were carried out in $25 \pm 1^{\circ} \mathrm{C}, \mathrm{pH} 7.0-7.5$, and a photoperiod of $16 \mathrm{~h}$ light: $8 \mathrm{~h}$ dark. The inoculation density of $B$. 
longirostris was 0.1 individuals $/ \mathrm{ml}$. In all cases, experiments started with female neonates less than $24 \mathrm{~h}$ old, randomly distributed in the experimental vessels. Following initiation of the experiments, we daily counted the number of living individual animals in each experimental tube and transferred them to test tubes containing fresh medium with the appropriate food levels. The experiments were terminated after 30 days, when most replicates showed a declining trend.

Based on collected data, we derived the rate of population increase per day $(r)$ using the following equation: $r=\left(\right.$ In Nt $\left.-\ln \mathrm{N}_{0}\right) / t$, where $\mathrm{N}_{0}=$ initial population density and $\mathrm{Nt}=$ population density after time $t$ (Nandini and Sarma, 2000). We used one-way analysis of variance (ANOVA) to statistically evaluate the differences between food types and densities on the rate of population increase and peak population abundances of the tested zooplankton. Differences were considered significant when $p<0.05$.

\section{Results}

Food density had a significant effect on the population growth of $B$. longirostris for both algal species (Figs. 1,2 ). In general, $B$. longirostris grew well on both types of algae, but consistently grew better with Scenedesmus than Chlorella. The highest $B$. longirostris population density $(7.1 \pm 2.08$ ind $/ \mathrm{ml}$ ) was obtained in the group of fed $0.2 \times 10^{6}$ cells $/ \mathrm{ml} \mathrm{S}$. subspicatus. The population density rapidly increased as the $S$. subspicatus density doubled to this level, but further increase did not result in a higher population density. The lowest population growth $(1.2 \pm 0.12)$ was recorded at the highest food density of $C$. vulgaris.

Population increase was positively related to feed density. In general, the lowest value $(0.106 \pm 0.002)$ was obtained at $0.05 \times 10^{6}$ cells $/ \mathrm{ml} \mathrm{C.} \mathrm{vulgaris}$ while the highest $(0.2 \pm 0.004)$ was obtained at $0.2 \times 10^{6}$ cells $/ \mathrm{ml} \mathrm{S}$. subspicatus. For both algae, the rate of population increase was significantly lower when density was only $0.05 \times 10^{6}$ cells $/ \mathrm{ml}$ than when the density was at its highest.

\section{Discussion}

Our results show that both population growth and the rate of population increase of $B$. longirostris were influenced by food type and density. The effect of food density on cladocerans may be quantified using population growth studies and life-table demography aspects. Further, population growth studies provide information on the effect of food level on individuals of various generations simultaneously occurring in a growing culture (Bocanegra et al., 2002; Nandini and Sarma, 2003).

It commonly occurs in laboratory tests that the population density of cladocerans increases as the algal density increases, up to a certain level (Nandini and Sarma, 2003). In the present work, the peak densities of $B$. longirostris fed $C$. vulgaris and $S$. subspicatus were 4.167 and $7.1 \mathrm{ind} / \mathrm{ml}$, respectively. In a study determining population growth of $B$. longirostris and $B$. fatalis in relation to algal food levels, the peak population growth values 


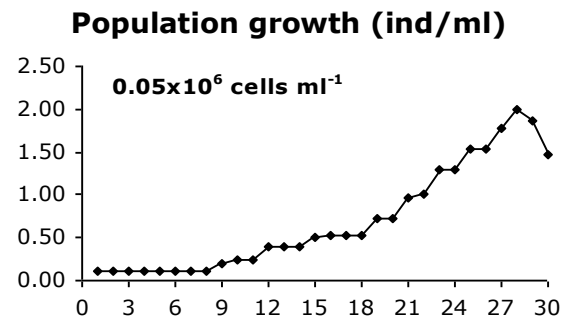

Rate of population increase/day
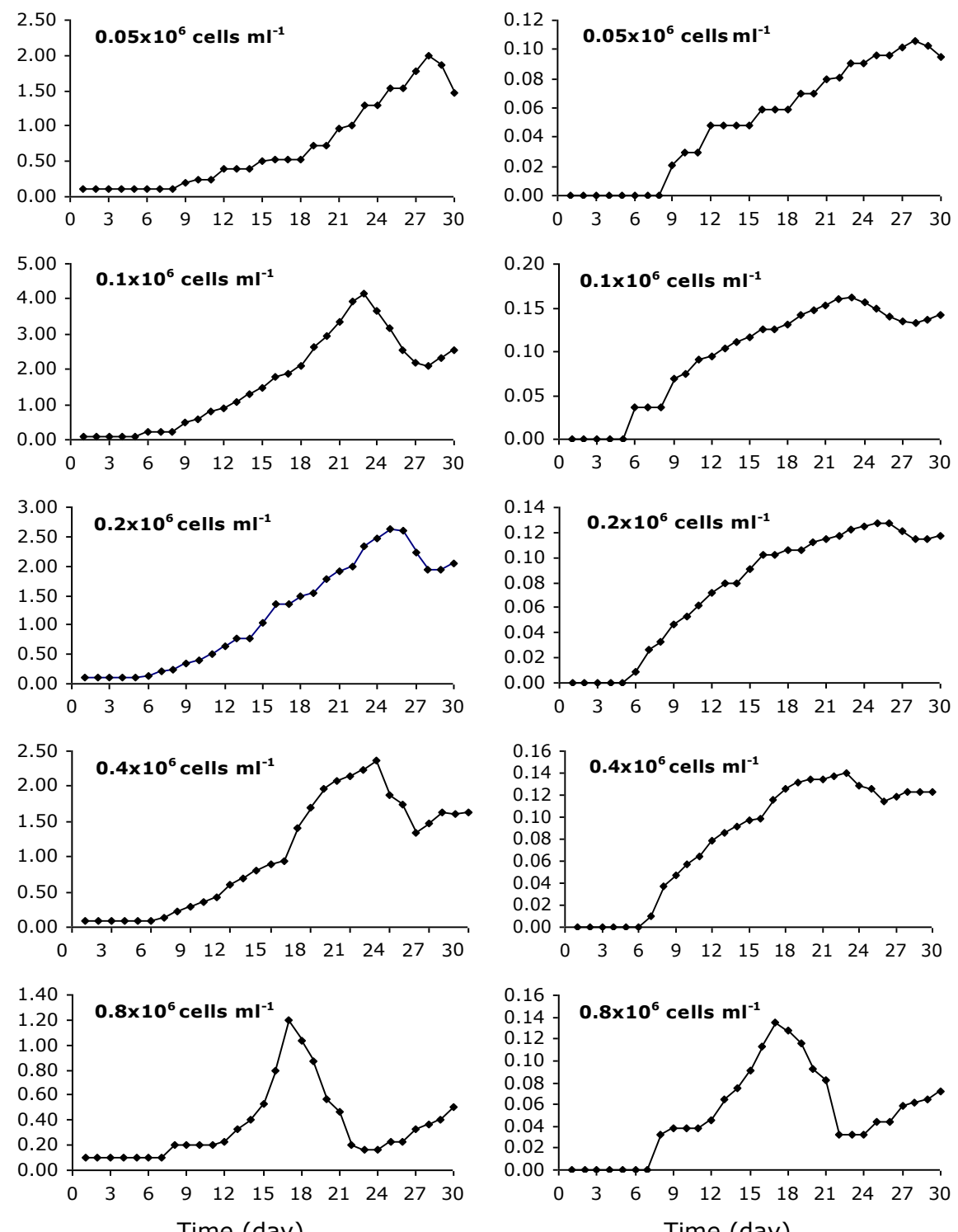

Time (day)

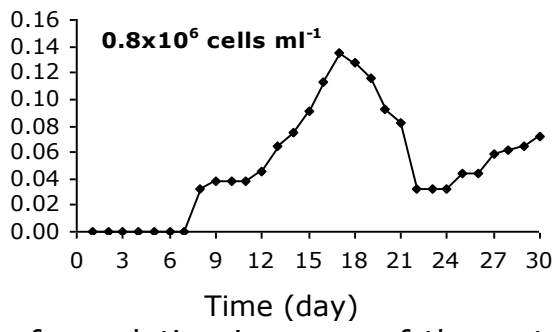

Fig. 1. Population growth and rate of population increase of the water flea, Bosmina longirostris, fed different densities of the alga, Chlorella vulgaris.

were 455 and 318 , respectively, in 100-ml test tubes containing $1.6 \times 10^{6}$ cells/ml of $C$. vulgaris (Hanazato and Yasuno, 1987). The peak population growths in our study are in the same approximate range.

The increase in number of $B$. longirostris that accompanies the increasing food density leads to a change in $r$ value. The $r$ values of cladocerans range 
Population growth (ind/ml)
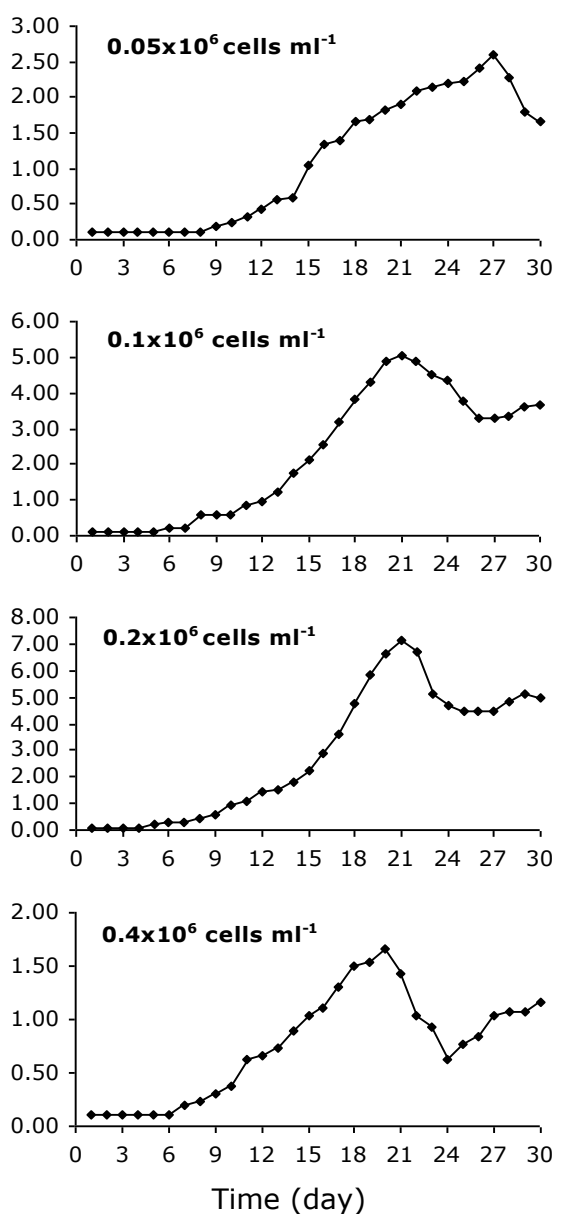

\section{Rate of population increase/day}
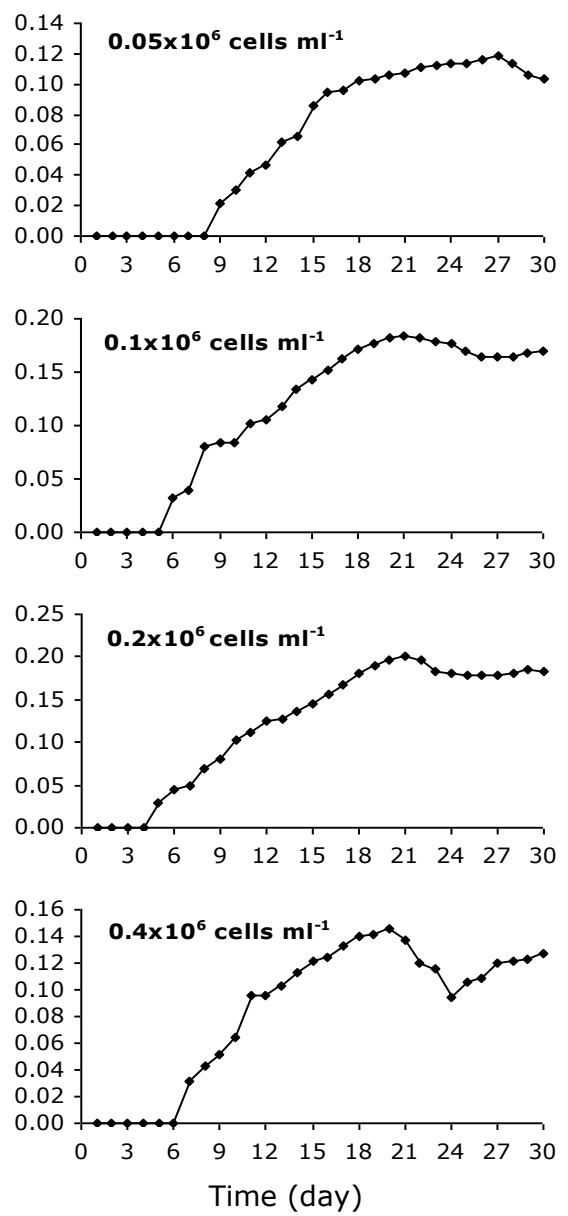

Fig. 2. Population growth and rate of population increase of the water flea, Bosmina longirostris, fed different densities of the alga, Scenedesmus subspicatus.

0.01-1.5 depending on the species, food type, temperature level, etc. (Nandini and Sarma, 2003). Using the life table demography approach, $r$ values range 0.17-0.23 for Ceriodaphnia cornuta, 0.54-0.60 for Moina macrocopa, 0.09-0.15 for Pleuroxus aduncus, and 0.12-0.28 for Simocephalus vetulus at food densities of $0.5-4.5 \times 10^{6}$ cells $/ \mathrm{ml}$ and, except for a few species of Daphnia and Moina, most cladocerans have population growth rates lower than 0.5/d (Nandini and Sarma, 2000). In Ceriodaphnia dubia and $M$. macrocopa, $r$ values vary 0.14-0.47/d (Flores-Burgos et al., 2003). In the present study, the $r$ values for $B$. Iongirostris varied $0.106-0.2 / d$, depending 
on food type and density, within the range observed for most zooplankton species.

Some rotifers and cladocerans are well-adapted to lower food levels. In such cases, increased algal density can cause a reduction in peak population density and $r$ value (Mangas-Ramirez et al., 2002). While small rotifer species are well adapted to low food levels, large species cannot survive and reproduce under such conditions (Stemberger and Gilbert, 1985). Several reasons have been adduced for the inhibitory properties of algal feed at high densities: too high densities can cause zooplankton death by the fouling effect of accumulated feces and uneaten food (Hirata, 1979), by decomposition of the algae's toxic products and secretions (Sarma and Rao, 1990), or by increased effort in food gathering (Nandini and Sarma, 2000). The inhibitory effect of C. vulgaris (above $0.1 \times 10^{6} \mathrm{cells} / \mathrm{ml}$ ) and S. subspicatus (above 0.2 $\times 10^{6} \mathrm{cells} / \mathrm{ml}$ ) on population growth of $B$. longirostris found in this study could be due to a combination of these factors.

In conclusion, the present study shows that under the culture conditions used in our experiments $S$. subspicatus is a suitable food for the culture of the freshwater cladoceran, $B$. longirostris. Since density and type of algae can be controlled in cladocera culture, the information discovered in this study can be useful for determining efficient aquaculture practices and ecosystem modeling.

\section{Acknowledgements}

We wish to thank the Research Grant Council of Süleyman Demirel University for financial support.

\section{References}

Abrantes N. and F. Gonçalves, 2003. The dynamics of Ceriodaphnia pulchella (Cladocera) in laboratory. Acta Oecologica, 24:245-249.

Benider A., Tifnouti A. and R. Pourriot, 2002. Growth of Moina macrocopa (Straus 1820) (Crustacea, Cladocera): influence of trophic conditions, population density and temperature. Hydrobiologia, 468:1-11.

Bocanegra M.D.H., Nandini S. and S.S.S Sarma, 2002. Combined effects of food level and inoculation density on competition between Brachionus patulus (Rotifera) and the cladocerans Ceriodaphnia dubia and Moina macrocopa. Hydrobiologia, 468:13-22.

Borowitzka M.A. and L.J. Borowitzka, 1988. Micro-algal Biotechnology. Cambridge Univ. Press, London.

Flores-Burgos J., Sarma S.S.S. and S. Nandini, 2003. Population growth of zooplankton (rotifers and cladocerans) fed Chlorella vulgaris and Scenedesmus acutus in different proportions. Acta Hydrochimica et Hydrobiologica, 31(3):240-248.

Hanazato T. and M. Yasuno, 1987. Experimental studies on competition between Bosmina longirostris and Bosmina fatalis. Hydrobiologia, 154:189199.

Hirata H., 1979. Culture methods of the marine rotifera, Brachionus plicatilis. Min. Rev. Data File Fish. Res., 1:27-46. 
Mangas-Ramirez E., Sarma S.S.S. and S. Nandini, 2002. Combined effects of algal (Chlorella vulgaris) density and ammonia concentration on the population dynamics of Ceriodaphnia dubia and Moina macrocopa (Cladocera). Ecotoxicol. Environ. Safety, 51:216-222.

Nandini S. and S.S.S. Sarma, 2000. Lifetable demography of four cladoceran species in relation to algal food (Chlorella vulgaris) density. Hydrobiologia, 435:117-126.

Nandini S. and S.S.S. Sarma, 2002. Competition between Moina macrocopa and Ceriodaphnia dubia: a life table demography study. Int. Rev. Hydrobiol., 87:85-95.

Nandini S. and S. S. S. Sarma, 2003. Population growth of some genera of cladocerans (Cladocera) in relation to algal food (Chlorella vulgaris) levels. Hydrobiologia, 491:211-219.

Ovie S.I. and A.B.M. Egborge, 2002. The effect of different algal densities of Scenedesmus acuminatus on the population growth of Moina micrura Kurz (Crustacea: Anomopoda, Moinidae). Hydrobiologia, 477:41-45.

Sarma S.S.S. and J.R. Rao, 1990. Population dynamics of Brachionus patulus Muller (Rotifera) in relation to food and temperature. Proc. Indian Acad. Sci. (Anim. Sci.), 99:335-343.

Stemberger R.S. and J.J. Gilbert, 1985. Body size, food concentration, and population growth in planktonic rotifers. Ecology, 66:1151-1159.

Vijverberg J. and H.P. Koelewijn, 2004. Effect of temperature on development and growth of the raptorial cladoceran Leptodora kindtii under laboratory conditions. Freshw. Biol., 49:1415-1422. 